\title{
Ascospore Deposition and Epiphytic Growth in Relation to Fungicide Timing for Control of Greasy Spot Rind Blotch Caused by Mycosphaerella citri
}

\author{
S. N. Mondal and L. W. Timmer, University of Florida, IFAS, Citrus Research and Education Center, Department \\ of Plant Pathology, 700 Experiment Station Road, Lake Alfred 33850 USA
}

\begin{abstract}
Mondal, S. N., and Timmer, L. W. 2005. Ascospore deposition and epiphytic growth in relation to fungicide timing for control of greasy spot rind blotch caused by Mycosphaerella citri. Plant Dis. 89:739-743.

Greasy spot rind blotch is a serious problem in Florida for the production of grapefruit (Citrus paradisi) for the fresh market. In the 1970s to the early 1980s, the disease was described in detail and the cause was determined to be Mycosphaerella citri, the same species responsible for greasy spot of foliage. The most appropriate timing for fungicide sprays was determined at that time, but peak ascospore release has changed in recent years. In the present study, the relationship of ascospore deposition and fungal growth on fruit was determined in order to more accurately time fungicide applications. Infection of fruit appears to occur similarly to that of leaves: by deposition of ascospores and germination to produce epiphytic growth followed by penetration of the fungus through stomata. Ascospore deposition occurred mostly in May and June, but epiphytic growth began only after the onset of the summer rainy season in June in 2002 and 2003. Ascospore deposition was lower in 2002 than in 2003, but development of epiphytic growth was similar in both years. Timing of fenbuconazole sprays was evaluated in the 2001, 2002, and 2003 seasons. Of the single-spray applications, those in July were the most effective, sprays in June and August were moderately effective, and those made in May or September were ineffective. Two- and three-spray programs from June through August were usually more effective than single sprays, and four monthly sprays from May to August were needed for a high level of control. Fungicide applications are needed about every 3 to 4 weeks after the beginning of the rainy season in June through August for a high level of control of rind blotch.
\end{abstract}

Additional keywords: citrus, disease management

Greasy spot rind blotch of citrus fruit was first described in Florida on grapefruit (Citrus paradisi) in 1958 (3). Symptoms consisted of minute black flecks on the fruit peel that appeared about the time the rind became fully colored in November or developed later in the season. Eventually, affected areas on the fruit coalesced and formed sunken pinkish-brown areas. The causal agent was unknown at the time, and the disease was usually referred to as pitting or pink pitting. Suit and DuCharme (4) consistently isolated a Cercospora-like fungus from affected fruit rind, but did not conduct pathogenicity tests. Whiteside $(9,12)$ described the symptoms in detail and showed that the black specks on fruit peel were attributable to necrosis of

Corresponding author: L. W. Timmer

E-mail: 1wt@crec.ifas.ufl.edu

This research was supported in part by the Florida Agricultural Experiment Station and approved for publication as Journal Series No. R-10416. This research was partially funded by the Florida Citrus Production Research Advisory Committee Project No. 043-07P.

Accepted for publication 10 March 2005.

DOI: 10.1094/PD-89-0739

(C) 2005 The American Phytopathological Society stomatal guard cells, and tissues eventually collapsed to form the pink pitting symptom. Whiteside $(9,12)$ reproduced symptoms of rind blotch by inoculating fruit with mycelial fragments and conidia of Mycosphaerella citri Whiteside, the same fungus that causes greasy spot on leaves $(6,10,11)$.

Some research has been conducted on the effectiveness and timing of fungicides for control of rind blotch $(4,12,15)$. Suit and DuCharme (4) found that copper fungicides, dithiocarbamates, and petroleum oil reduced rind blotch incidence. They concluded that May applications were relatively ineffective and the best spray timing was mid-July, but none of their data were statistically analyzed. Whiteside (12) found that tribasic copper sulfate, petroleum oil, captafol, zineb, and benomyl were effective for rind blotch control. Applications on 26 June and 12 August were more effective than those made on 7 May. In subsequent studies, Whiteside (15) found that basic copper sulfate and benomyl were more effective than petroleum oil for rind blotch control. Single applications in June or July were generally more effective than those made in May or August.

Current recommendations for the timing of fungicide applications (5) are still based on the results obtained in the 1970s and early 1980s $(4,12,15)$. However, since that time, cultural practices have been modified resulting in changes in peak spore releases from June and July in the 1970s $(10,14)$ to April and May in recent years $(1,2,7,8)$. Despite the fact that most of the ascospores are released in April and May, epiphytic growth of the fungus does not develop rapidly on spring growth foliage until the rainy season begins in June (2). In contrast, epiphytic growth on the summer flush leaves develops rapidly since conditions are favorable at that time of year (2). Thus, recommendations for the best timing of sprays for foliar greasy spot have been modified (5). Currently, we recommend a single spray from midMay through June to control greasy spot of spring growth leaves and a second application in July or August for summer growth leaves.

Most of the fruit infection is presumed to develop from ascospore inoculum as does leaf infection (6), even though Koch's postulates were completed using conidia and mycelial inoculum (12). Whiteside (12) suggested that epiphytic growth occurred on fruit, but this has never been clearly established. The purpose of this study was to determine the pattern of ascospore deposition and development of epiphytic growth on the fruit surface and to determine the number and timing of fungicide applications required to control rind blotch.

\section{MATERIALS AND METHODS}

Development of epiphytic growth. Ten fruit were inoculated with ascospores of M. citri in order to make observations on germination and growth of the fungus on the fruit surface. Fruit of Marsh grapefruit growing in the field were sprayed with $70 \%$ ethanol and covered individually with paper bags on 5 May 2003 when fruit were about $2 \mathrm{~cm}$ in diameter to minimize natural infection or contamination of the fruit surface by other fungi. Ascospores for the inoculations were collected from naturally infected, decomposing leaves that had been placed in a wind tunnel as described previously (1). In May 2003, when conditions were dry, and again during the rainy season when conditions were favorable for greasy spot infections in June and July, bags were removed from the fruit, fruit were spray inoculated with $10^{3}$ ascospores per $\mathrm{ml}$, and then the bags were replaced immediately. 
Two fruit were collected every 2 weeks after inoculation, and several areas of the peel of about $1 \mathrm{~cm}^{2}$ each were removed from different parts of the fruit. Tissue samples were fixed in 3\% glutaraldehyde in $0.1 \mathrm{M}$ potassium, phosphate buffer, $\mathrm{pH}$ 7.2 , for $4 \mathrm{~h}$ at room temperature (23 to $25^{\circ} \mathrm{C}$ ), rinsed with buffer, postfixed in $2.0 \% \mathrm{OsO}_{4}$ in the same buffer for the same time, and then rinsed again with buffer. Tissue pieces were dehydrated in with a Bomar Critical-Point Drier (Bomar Co., Tacoma, WA). Specimens were mounted on SEM stubs, coated with goldan ethanol series and critical-point dried

palladium, and viewed with a JEOL JSM 35 scanning electron microscope.

Time of ascospore deposition and growth. Ascospore deposition and the development of epiphytic growth were followed in a Marsh grapefruit grove near Lake Alfred, FL, from March to July in 2002 and 2003. On each sampling date, two fruit were collected from each of six trees. Five areas of each fruit were examined either by attaching double-stick scotch tape to the fruit or by painting the fruit with a 50:50 mixture of fingernail polish and acetone and allowing it to dry. The tape or the dried film was removed
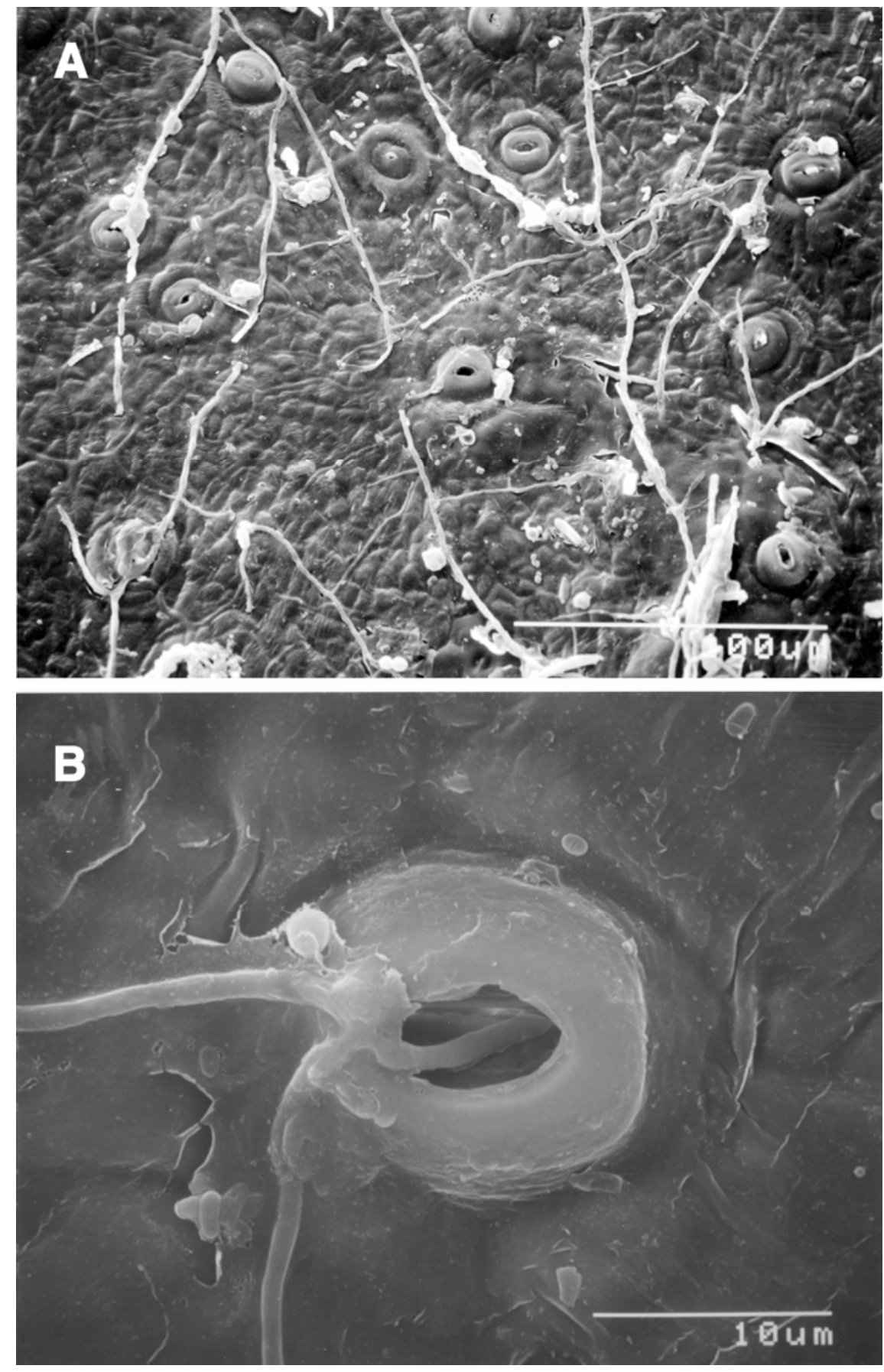

Fig. 1. Scanning electron micrograph of Mycosphaerella citri on the surface of grapefruit. A, Ramifying hyphae on the fruit surface 21 days after inoculation. Bar $=100 \mu \mathrm{m}$. B, Hypha penetrating a stomate on the fruit surface. $\mathrm{Bar}=10 \mu \mathrm{m}$. from the fruit and mounted on a microscope slide and stained with cotton blue (aqueous solution of $25 \%$ glycerol [vol/vol], $10 \%$ lactic acid [vol/vol], and $0.05 \%$ [wt/vol] cotton blue). Ten microscope fields on each area of the fruit were examined at $\times 160$ and the number of ascospores counted. Counts were averaged on all areas of the fruit and across all fruit and expressed as the number of ascospores per $\mathrm{cm}^{2}$ of fruit surface. In each microscope field, epiphytic growth was rated on a scale of $0=$ no growth; 1 = scattered hyphae, $<10 \%$ coverage; $2=10$ to $25 \%$ coverage; 3 $=26$ to $75 \%$ coverage; $4=76$ to $100 \%$ coverage; and $5=$ dense growth covering the entire surface (2).

Fungicide timing. Application times for greasy spot rind blotch control were evaluated in Marsh grapefruit groves near Lake Alfred in 2001, 2002, and 2003. The grove used in 2001 was over 30 years old, had not been treated for greasy spot for many years, and had a high level of greasy spot. The grove used in 2002 and 2003 was about 15 years old and had lower levels of greasy spot. Timing treatments were replicated on six single trees in a randomized complete block design. Fenbuconazole (Enable 2F) was used for all applications since it is highly effective for rind blotch control (2) and is recommended commercially in Florida (5). On each application date (see below), about 100 fruit per tree were sprayed with a hand-pump sprayer using fenbuconazole (Enable 2F) at 0.5 $\mathrm{ml} /$ liter of water. That concentration is approximately equivalent to the commercial rate of 0.6 liter/ha $(8.0 \mathrm{fl} \mathrm{oz} / \mathrm{acre})$ if a spray volume of 1,200 liters/ha (125 $\mathrm{gal} / \mathrm{acre}$ ) is used.

In 2001, single treatments in July, August, and September were compared to two-spray programs of July-August and July-September and an unsprayed control. Spray applications were made on 15 July, 15 August, and 1 September for treatments that included those months. In 2002, single-spray treatment in May, June, July, and August were compared with two-spray programs in May-June, June-July, July-August, a four-spray program from May to August, and an unsprayed control. Spray applications were made on 15 May, 16 June, 15 July, and 17 August for treatments that included those months. In 2003, the programs were the same as in 2002 except that a three-spray program in June-July-August was added. Spray dates were 17 May, 23 June, 17 July, and 13 August for treatments that included those months.

Two fruit were collected from each treatment tree in August or September to assess the effect of fungicide sprays on epiphytic growth. Samples from the fungicide plots were processed as above to determine the density of the epiphytic growth with each treatment program. Epiphytic growth was evaluated on 30 September 
2001, 30 August 2002, and 1 September 2003.

In late December each year, disease severity was evaluated on about 50 fruit on each of the treatment trees on a scale of 0 $=$ none, $1=1$ to $20 \%$ of the area affected, $2=21$ to $40 \%, 3=41$ to $60 \%, 4=61$ to $80 \%$, and $5=$ more than $80 \%$. Disease incidence was the percentage of symptomatic fruit. Epiphytic growth ratings, disease incidence, and severity in each fungicide timing experiment were subjected to analysis of variance and means separated using the Waller-Duncan $k$-ratio $t$ test, $P \leq$ 0.05 .

\section{RESULTS}

Development of epiphytic growth. Ascospores germinated on the surface of the fruit, and epiphytic growth formed (Fig. 1A). Fruit inoculated with ascospores in May during dry weather developed little epiphytic growth, but abundant mycelium formed on fruit inoculated during rainy weather in June and July. After some mycelial growth, hyphal tips penetrated the fruit through stomata (Fig. 1B).

Time of ascospore deposition and epiphytic growth. The number of ascospores deposited on fruit in 2002 was relatively low compared with the very high numbers in the same grove in 2003 (Fig. 2A). Ascospore deposition began in March and April and increased in May and June. After June in both years, readings were discontinued because it was very difficult to see the ascospores in the midst of dense epiphytic mycelial growth.

Despite the fact that many ascospores were deposited before June, little epiphytic growth developed before the rainy season began in June (Fig. 2B and C). After that, epiphytic growth developed rapidly and increased until the end of the rainy season in September. Despite the difference in the numbers of ascospores deposited between 2002 and 2003, the amount of epiphytic growth that developed in both years was similar.

Fungicide timing. In 2001, rind blotch was severe since the grove used for experiments had not been sprayed for greasy spot for many years. All of the spray treatments had significantly less epiphytic growth compared with the unsprayed control (Fig. 3A). The July-August program reduced epiphytic growth more than any other treatment schedule. Only the JulyAugust program had a lower incidence of rind blotch than the unsprayed control (Fig. 3B). All but the September treatment schedule had significantly lower disease severity than the unsprayed control; however, the July-August program was the most effective.

In 2002, rind blotch incidence and severity were much lower than in 2001 (Figs. 3 and 4). All single-spray treatments significantly reduced epiphytic growth compared with the unsprayed control, but the July treatment spray was the most effective in 2002. Two-spray programs were generally more effective than the single-spray treatments, but not significantly better than a single spray in July (Fig. 4A). Leaves from the fourspray program had considerably less epiphytic growth than the unsprayed control. Of the single-spray programs, the July spray had lower rind blotch incidence and severity than the others (Fig. 4B). All of the two-spray programs had lower disease incidence, but not disease severity than a single July spray. The four-spray program had lower incidence than any other program and had lower severity than any program except the June-July two-spray schedule.

In 2003, all single-spray treatments reduced epiphytic growth compared with the unsprayed control, but the May spray was less effective than the others (Fig. 5A). Two- and three-spray programs were no more effective than single sprays in June or July, but the four-spray program was better than the single-spray treatments in reducing epiphytic growth. With regard to reducing rind blotch incidence and severity, single sprays in June, July, or August were effective, but the May treatment was not (Fig. 5B). The two-spray programs were no more effective than a single spray
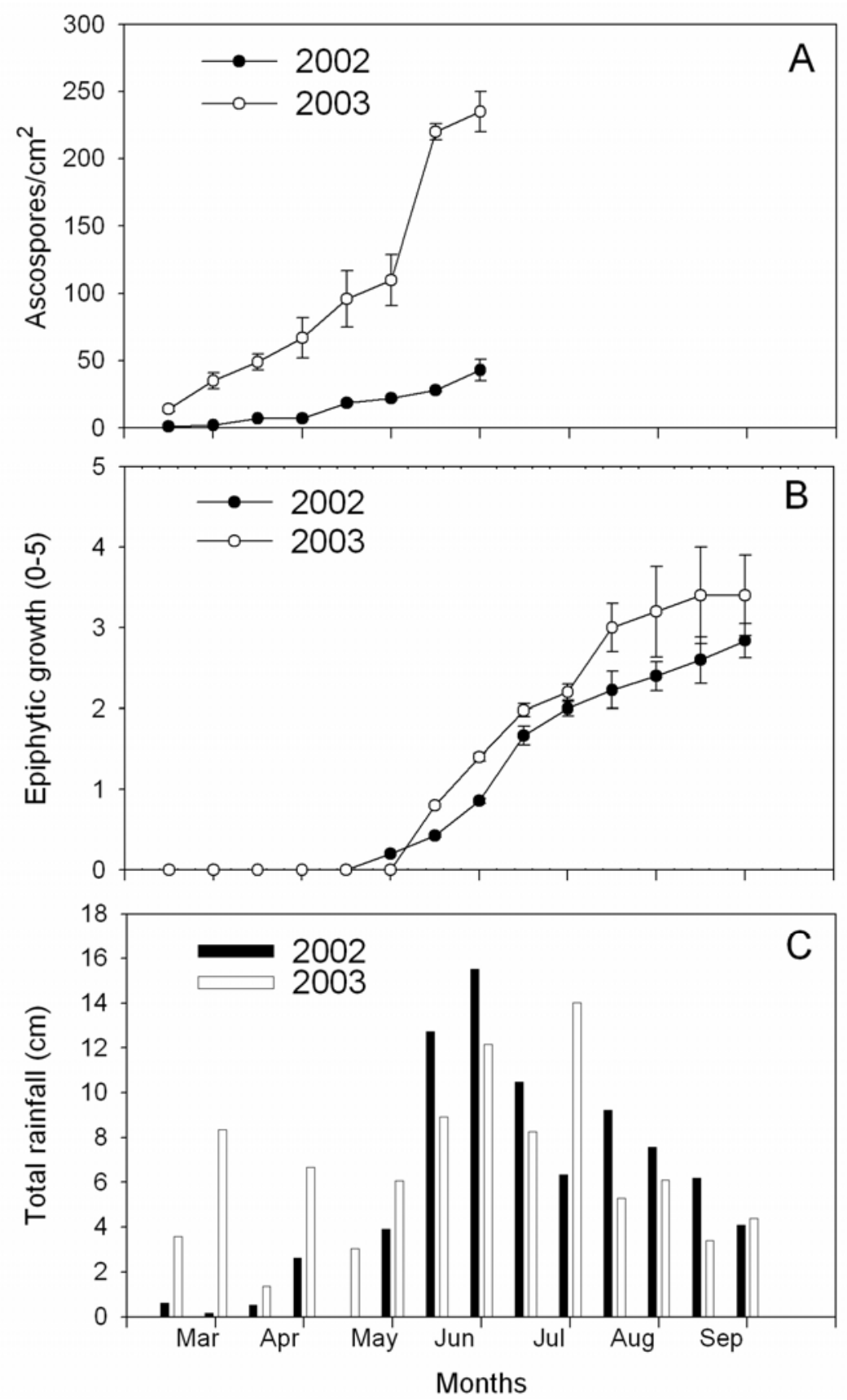

Fig. 2. Ascospore deposition and epiphytic growth on the surface of grapefruit. A, Numbers of ascospores deposited in 2002 and 2003. B, Development of epiphytic growth on the fruit surface in 2002 and 2003. C, Biweekly rainfall total during the summer season. Bars on each point represent standard error of the mean of observations. 

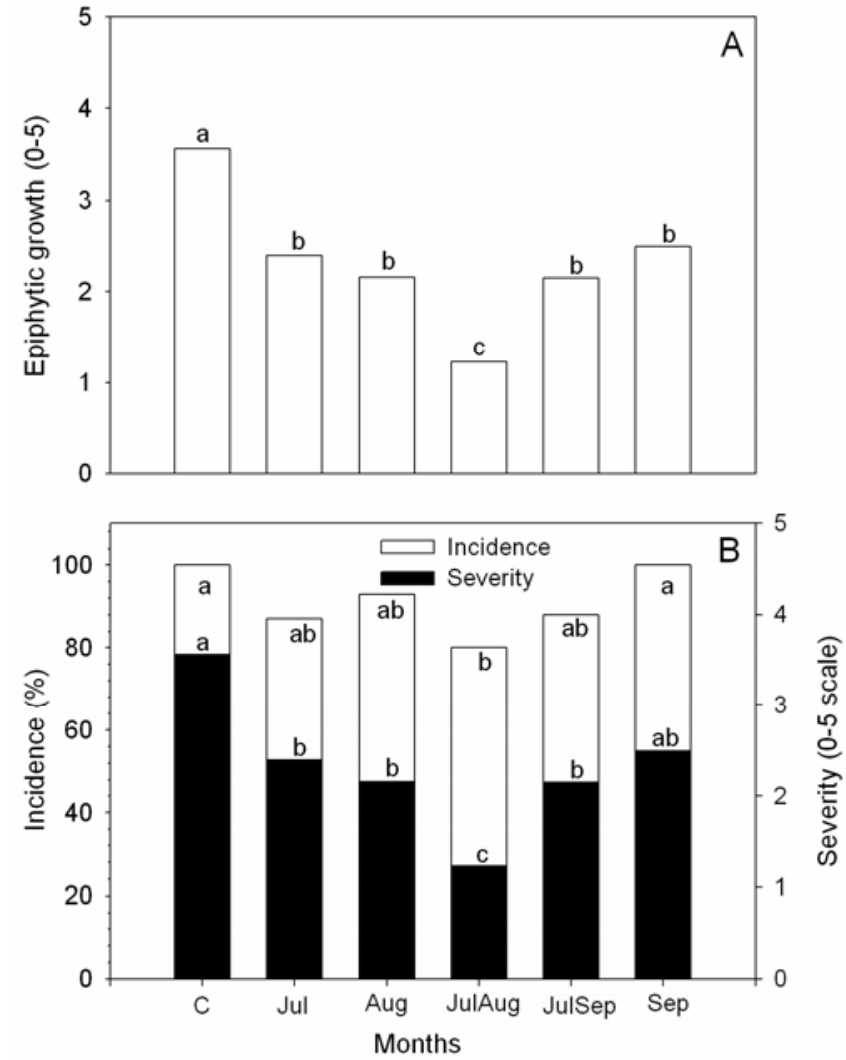

Fig. 3. Effect of timing of fenbuconazole applications on: A, density of epiphytic growth of Mycosphaerella citri on grapefruit rind, and $\mathbf{B}$, incidence and severity of rind blotch in 2001. Applications were made in July (Jul), August (Aug), September (Sep), or some combination of those dates in 2001 and compared with an unsprayed control (C). Mean separation by the Waller-Duncan $k$-ratio $t$ test, $P \leq 0.05$.
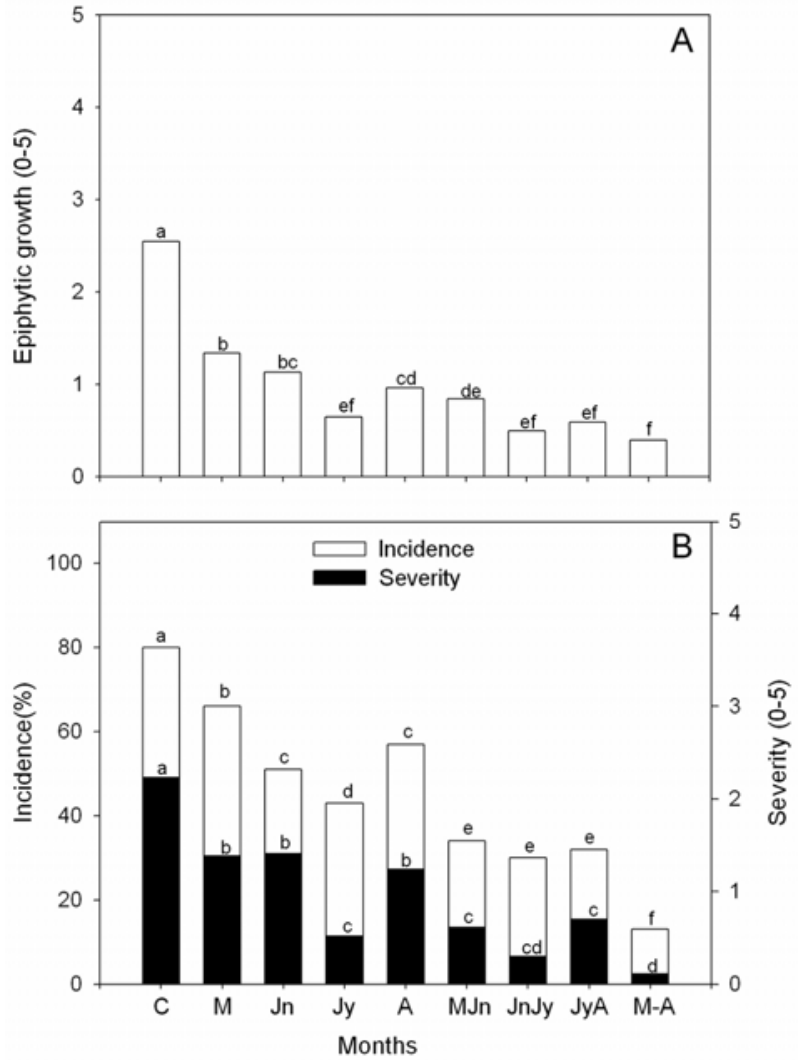

Fig. 4. Effect of timing of fenbuconazole applications on: A, density of epiphytic growth of Mycosphaerella citri on grapefruit rind, and $\mathbf{B}$, incidence and severity of rind blotch in 2002. Applications were made in May (M), June (Jn), July (Jy), or August (A) or some combination of those dates in 2002 and compared with an unsprayed control (C). Mean separation by the Waller-Duncan $k$-ratio $t$ test, $P \leq 0.05$. in July. The three-spray program was usually significantly better than the single sprays, and the four-spray program had very little rind blotch.

\section{DISCUSSION}

Most of the ascospores of $M$. citri are released in April and May $(1,2)$. In this study, deposition on fruit began about that time but continued through June. On leaves, ascospores germinate and develop extensive epiphytic mycelial growth prior to infection through the stomates $(2,13,14)$. Whiteside (12) suggested that infection of fruit progressed in a similar fashion, but no studies had been conducted on fruit to confirm this idea. The current study indicates that infection of leaves and fruit proceeds in a similar manner and that most of the infection on fruit is also probably due to ascospore inoculum.

Epiphytic growth does not develop on leaves until the rainy season begins $(2,10)$. In the current study, epiphytic growth on fruit began to develop at the start of the rainy season in June and increased steadily through the end of the rainy season in September. Thus, despite the fact that peak ascospore release now occurs in April-May $(1,2,7,8)$ rather than June-July as occurred in the 1970s $(10,14)$, epiphytic growth still occurs at the same time as in earlier years.
Epiphytic growth is highly dependent on frequent rains and high humidity (13), but not necessarily on the amount of rainfall. In central Florida, rainfall in the spring is associated with the passage of cold fronts, and humid conditions do not prevail at that time of year. The number of ascospores available appears to be of lesser importance. Epiphytic growth was similar in 2002 and 2003 despite the fact that the number of ascospores deposited was about five times higher in 2003. Ascospores deposited prior to the beginning of the rainy season apparently did not survive and germinate. Ascospores are not long-lived if conditions are not favorable for germination and infection (13), but low numbers of ascospores can produce substantial epiphytic growth if conditions are favorable (2).

Previous studies $(4,12,15)$ indicated that single fungicide applications in June, July, or August provided good control of rind blotch. Our study produced similar results, and it appears that a single fungicide application in July provides effective control of rind blotch. Thus, since epiphytic growth still occurs during the summer rainy season, the optimal time of application has not changed even though the time of peak ascospore release has changed due to different cultural practices. A single application in July, however, may not be sufficient to attain a high level of control, and June and August sprays may be needed as well to produce fruit free of rind blotch. Thus, fruit must be protected from the beginning of the rainy season until ascospore inoculum is exhausted about the end of August. In contrast, spring growth leaves are protected by a single spray applied anytime before the rainy season begins or up to 3 weeks thereafter. Summer growth must be protected within 3 to 4 weeks after emergence since it occurs when conditions are favorable for infection.

Rind blotch is most serious on grapefruit and much less of a problem on oranges and other citrus species $(5,6)$. Producers of grapefruit for the fresh market must protect fruit from melanose, caused by Diaporthe citri, as well as rind blotch (5). Melanose is controlled by applications of copper or strobilurin fungicides from petal fall until late June, at which time fruit becomes resistant to this disease. These fungicides will also protect fruit from rind blotch; thus, an additional fungicide application in July should provide adequate control of rind blotch. Where an exceptional degree of control is desired, such as for fruit intended for the export or gift fruit market, 

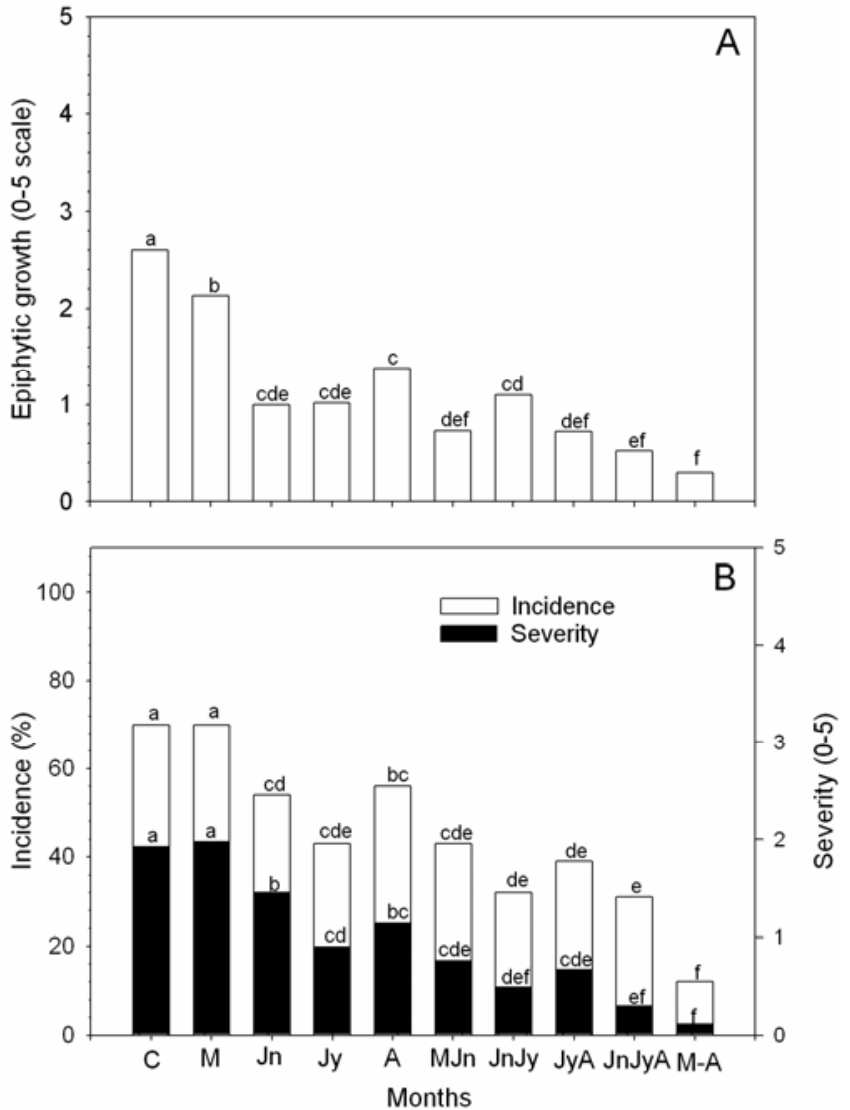

Fig. 5. Effect of timing of fenbuconazole applications on: A, density of epiphytic growth of Mycosphaerella citri on grapefruit rind, and $\mathbf{B}$, incidence and severity of rind blotch in 2003. Applications were made in May (M), June (Jn), July (Jy), or August (A) or some combination of those dates in 2003 and compared with an unsprayed control (C). Mean separation by the Waller-Duncan $k$-ratio $t$ test, $P \leq 0.05$.

a spray in August can be added to maximize control.

\section{ACKNOWLEDGMENTS}

The authors gratefully acknowledge the technical assistance of C. L. Geanangel and T. Johnston and the assistance with electron microscopy of Diann Achor.

\section{LITERATURE CITED}

1. Mondal, S. N., and Timmer, L. W. 2002. Environmental factors affecting pseudothecial development and ascospore production of $M y$ cosphaerella citri, the cause of citrus greasy spot. Phytopathology 92:1267-1275.

2. Mondal, S. N., and Timmer, L. W. 2003. Relationship of epiphytic growth of Mycosphae- rella citri to greasy spot development on citrus and to disease control with fenbuconazole Plant Dis. 87:186-192.

3. Pratt, R. M. 1958. Florida Guide to Citrus Insects, Diseases, and Nutritional Disorders. University of Florida Press, Gainesville.

4. Suit, R. F., and DuCharme, E. P. 1971. Cause and control of pink pitting on grapefruit. Plant Dis. Rep. 55:923-926.

5. Timmer, L. W., ed. 2004. 2004 Florida Citrus Pest Management Guide. University of Florida, IFAS, Publ. No. SP-43.

6. Timmer, L. W., and Gottwald, T. R. 2000 Greasy spot and similar diseases. Pages 25-28 in: Compendium of Citrus Diseases. L. W. Timmer, S. M. Garnsey, and J. H. Graham, eds. American Phytopathological Society, St. Paul, MN.

7. Timmer, L. W., Gottwald, T. R., McGovern, R. J., and Zitko, S. E. 1995. Time of ascospore release and infection by Mycosphaerella citri in central and southwest Florida. Proc. Fla. State Hortic. Soc. 108:374-377.

8. Timmer, L. W., Roberts, P. D., Darhower, H M., Bushong, P. M., Stover, E. W., Peever, T. L., and Ibáñez, A. M. 2000. Epidemiology and control of citrus greasy spot in different citrusgrowing areas in Florida. Plant Dis. 84:1294 1298.

9. Whiteside, J. O. 1970. Symptomatology of orange fruit infected by the greasy spot fungus Phytopathology 60:1859-1860.

10. Whiteside, J. O. 1970. Etiology and epidemiology of citrus greasy spot. Phytopathology 60:1409-1414.

11. Whiteside, J. O. 1972. Histopathology of citrus greasy spot and identification of the causal fungus. Phytopathology 62:260-263.

12. Whiteside, J. O. 1972. Blemishes on citrus rind caused by Mycosphaerella citri. Plant Dis. Rep. 56:671-675.

13. Whiteside, J. O. 1974. Environmental factors affecting infection of citrus leaves by $M y$ cosphaerella citri. Phytopathology 64:115 120.

14. Whiteside, J. O. 1977. Behavior and control of greasy spot in Florida citrus groves. Proc. Intl. Soc. Citricult. 3:981-986.

15. Whiteside, J. O. 1982. Timing of single-spray treatments for optimal control of greasy spot on grapefruit leaves and fruit. Plant Dis. 66:687-690. 